\title{
Modelling Consumer Preferences for Electric Vehicles in Portugal: an Exploratory Study
}

\author{
Gabriela Duarte Oliveira \\ Department: DEM - Mechanic Engineering Department \\ MIT Portugal Program, University of Coimbra and INESC Coimbra \\ Coimbra \\ Portugal \\ Luís Miguel Cândido Dias \\ FEUC - Faculty of Economics \\ University of Coimbra and INESC Coimbra \\ Coimbra \\ Portugal \\ Paula Cristina Sarabando dos Santos \\ ESTGV - Superior School of Technology and Management of Viseu \\ Polytechnic Institute of Viseu and INESC Coimbra \\ Viseu \\ Portugal
}

This is a PDF file of an unedited manuscript that has been accepted for publication in Management of Environmental Quality.

The manuscript will undergo copyediting, typesetting, and review of the resulting proof before it is published in its final form. Please note that during the production process errors may be discovered which could affect the content, and all legal disclaimers that apply to the journal pertain. The final version will be available at:

http://www.emeraldinsight.com/doi/abs/10.1108/MEQ-03-2014-0047 
Title:

Modelling Consumer Preferences for Electric Vehicles in Portugal: an Exploratory Study

Abstract:

- Purpose: This study aims at understanding consumer preferences concerning Electric Vehicles (EV) in Portugal, based on comparisons with other vehicles with different powertrains.

- Design/methodology/approach: The analysis incorporated two survey-based approaches: Choice-Based Conjoint Analysis (CBC) and Multicriteria Decision Analysis-based (MCDA). The survey interviewed 252 respondents. The criteria characterizing each vehicle are purchase price, range, fuel consumption and $\mathrm{CO}_{2}$ emissions. Another criterion was added to verify the potential of EV privileges to influence consumer preferences. A sensitivity analysis on the influence of purchase price and fuel price in the global utility of the vehicles was performed.

- Findings: The results showed that monetary criteria are those influencing vehicle purchase decisions the most, whereas the existence of privileges for EV owners has little relevance. EV are chosen by the consumer only if their price decreases or if gasoline and diesel prices increase sharply. The position of PHEV in the rankings makes the promotion of this type of vehicle an interesting path to exploit as potential intermediates to the diffusion of EV.

- Practical implications: The results underline the need of improving technical barriers of EV that are responsible for consumers' relevant concerns and that a price subsidy could eventually be effective to increase EV sales at its current market price.

- Originality/value: This study compares a wide range of vehicles (conventional, hybrid, and electric), addresses the Portuguese market, and proposes an MCDA-based approach to obtain preference information, which is compared with a CBC approach.

Keywords: Electric vehicles, Consumer preferences, Choice-Based Conjoint Analysis, Multicriteria Decision Analysis 


\section{Introduction}

Currently, the European transportation sector raises many environmental and energy independence concerns. In Portugal, transportation is responsible for about $40 \%$ of the overall energy consumption, mainly from oil derivatives (95\%) (EUROSTAT, 2011), revealing a high dependency on oil and a significant environmental burden. In particular, road transportation is associated with over $80 \%$ of this energy demand. Facing this problem, the Portuguese government has been promoting energy efficiency and electric mobility through the development of programs (such as the National Plan of Action for Energy Efficiency, in the transportation sector, and the Mobi.e program, an electric mobility network supported by a technologic platform) and also through specific measures to encourage the purchase of Electric Vehicles (EV) over the traditional ones (internal combustion engine vehicles), due to their potential advantages in environmental performance and oil independence. In this context, 1036 charging stations were built and EV purchases were subsidized with $5,000 €$ (only for individual consumers). Companies were granted fiscal benefits derived from acquisitions of environmentally related products, as a way of increasing energy efficiency (Martins, 2011). EV purchases were encouraged by credits on taxes and tax exemption of EV expenditures. Additional policies ensued, such as a circulation tax exemption, exclusive parking places and the right to travel on high occupancy lanes. However, these policies, which started in 2010, were not as effective as it was expected: in 2011-2012, only 289 EV were sold, according to the Automobile Association of Portugal (ACAP), mostly by public institutions and private companies. These results positioned the Portuguese market in one of the worst performances in the European transports field.

There are some possible explanations for the failure of a mass introduction of EV in the Portuguese market. Firstly, these policies were introduced in a context of economic crisis, which affected the demand for passenger light-duty vehicles overall. Another explanation for the low adoption of EV could be the lack of prior knowledge among consumers, considered as a key determinant of acceptability of new vehicle technologies (Thesen and Langhelle, 2008). However, previous studies suggest the use of government policies (subsidies and/or tax incentives) to increase Alternative Fuel Vehicles (AFV) sales is generally effective (e.g. Green and Srinivasan, 1978a; Ewing and Sarigöllü, 2000; Gallagher and Muehlegger, 2007; Caulfield et al., 2010; Hidrue et al., 2011).

On the demand side, consumer preferences have been identified as the most relevant factor to predict changes in the vehicles market (Ahn et al., 2008). According to Garling and Thogersen (2001), obtaining a satisfactory match between product characteristics and consumer preferences is crucial for increasing market share. Thus, the broad goal of the present study is to provide insight on consumer preferences about EV in Portugal by answering the following research questions:

R1: Which criteria consumers value the most in a vehicle purchase decision?

R2: What is the sensitivity of consumer utilities to changes in the vehicle criteria?

R3: Do EV privileges (such as reserved parking spots) play a significant role for Portuguese consumers?

To answer these questions, two survey-based approaches were used. According to Novemsky et al. (2007), one of the elements that consumer preferences depend on is the elicitation task. Therefore, two distinct tasks were made in order to allow us to compare results. Firstly, Conjoint Analysis (CA) was employed, which is a popular approach to study consumer preferences, as detailed in the following sections. For that purpose a stated preference survey was designed and applied to collect data from consumers by means of a decomposition approach. In parallel, a Multi-Criteria Decision Analysis (MCDA)-based questionnaire was used to collect preference data, in which respondents had a more direct role, not only in the assessment of performance levels, by defining their own utility functions, but also by directly assigning weights to each criterion (composition approach). This requires more detailed information from each respondent surveyed, but yields more detailed results. One question of interest is thus to find out whether the results of the two data-collection approaches are in agreement. As a note, Chéron and Zins (1997) used also two data collection techniques (CA and the Nominal Group Technique) to explore the relative importance of the criteria that could be determinant to discourage consumers from purchasing an EV. The main contribution of this paper is to provide a detailed analysis of consumer preferences in Portugal, deriving insights about which policies can potentially increase the circulation of more environmentally friendly vehicles. 
Section 2 presents the literature review on consumer preferences for $E V$, followed by the research methodology and study description in section 3. Section 4 presents and discusses the results obtained in this research and the main conclusions can be found in section 5 .

\section{Literature Review}

This review has two parts. Section 2.1 focuses on consumer preference studies for EV. Section 2.2 focuses on consumer preference studies that compute part-worth utilities, i.e., the utilities corresponding to the different criterion levels.

\subsection{Consumer preference studies for $E V$}

When it comes to the introduction of new products, such as AFV, the fact that consumers have generally no previous contact with the product makes it harder to anticipate their preferences (Steiner et al., 2011). This has led to an extensive body of research of consumer preferences about EV or, more generally, AFV (which include other fuels such as natural gas or hydrogen) in the last three decades (e.g. Bunch et al., 1993; Golob et al., 1993; Tompkins and Bunch, 1998; Ewing and Sarigöllü, 1998; Kavalec, 1999; Brownstone et al., 2000; Potoglou and Kanaroglou, 2007; Caulfield et al., 2010; Lin and Greene, 2010; Qian and Soopramanien, 2011; Hoen and Koetse, 2012; Hackbarth and Madlener, 2013).

Table I lists the studies that focused on EV allowing to identify some trends. First, in the beginning, most of the studies were developed in North America (mainly USA); however, this trend has been changing since 2010 as more studies started to be developed for European countries. Second, the most common approach has been to collect stated preference data and to use disaggregate models (CA or discrete choice methods) to represent consumer preferences (Beggs et al., 1981; Calfee, 1985; Segal, 1995; Chéron and Zins, 1997; Krems et al., 2010; Zhang et al., 2011; Eggers and Eggers, 2011; Glerum et al., 2011, 2013; Hidrue et al., 2011; Ziegler, 2012; Lebeau et al., 2012; Jensen et al., 2013). These approaches are able to forecast the demand for new products (Beggs et al., 1981; Zhang et al., 2011) and allow analysing in detail the product characteristics, before the introduction of these products in the market (Krems et al., 2010), which are pointed out as the main reasons for this choice. And third, studies focused on EV usually compared these vehicles only with Conventional Vehicles $(\mathrm{CV})$, with the exception of some studies that included other vehicles in the comparison: HEV and Natural Gas Vehicles (NGV) (Kurani et al., 1996), HEV (Eggers and Eggers, 2011), Plug-in Hybrid Electric Vehicles (PHEV) (Lebeau et al., 2012), Compressed Natural Gas Vehicles and Fuel Cell Vehicles (Ziegler, 2012). The present paper contributes to this literature by comparing a wide range of vehicles (Battery Electric Vehicles - BEV, PHEV, HEV, Diesel, Gasoline) and by addressing the Portuguese market.

\subsection{Part-worth utilities estimation studies}

Table II summarizes the studies that modelled consumer preferences for AFV, based on part-worth utilities. The most frequent analysis was the computation of the relative importance of criteria (Segal, 1995; Wu et al., 2014), by crossing the importance with consumer demographics (Kabaday et al., 2013), or by comparing the results with other data obtained through another data collection method (Chéron and Zins, 1997). Some studies plotted also part-worth utility functions. Ewing and Sarigöllü (2000) used the criteria coefficients obtained through the Multinomial Logit (MNL) model to plot part-worth utility functions for each criterion, without, however, rescaling the coefficients in order for their sum (within each attribute) to be equal to zero, a common procedure before plotting utility functions in CA. Wu et al. (2014) used rescaled part-worth utilities to plot criteria utility functions; however, the research design only included two levels for each criterion, which does not allow capturing non-linear effects. Eggers and Eggers (2011) presented a preference distribution of the part-worth utility levels. The present paper contributes to this literature by proposing an MCDA-based approach to obtain distributions for part-worth utilities and criteria weights and comparing it with a traditional CA approach. 
$<$ Table I $>$

$<$ Table II $>$

\section{Methodology}

\subsection{The CA model}

CA was developed within the conjoint measurement area, in mathematical psychology, by Luke and Tukey in 1964, and later it was extended to marketing research (Green et al., 2001; Kuhfeld, 2010). Through the analysis of the trade-offs between criteria (when seeking the preferred balance between criteria levels, consumers have to give up performance on some criteria in order to have gains in other criteria) CA exploits the consumers' decision process by defining which are the most determinant criteria and the most preferred combinations of criteria levels (Green et al., 2001; Kuhfeld, 2010). This method can be defined as a technique to measure trade-offs implicit in survey responses concerning consumer preferences and purchase intentions, and a method to simulate how consumers react to changes in existing products or services or to the introduction of new ones as well (Green et al., 2001). This explains why CA has been frequently used to assess consumer preferences about vehicle choice (Segal, 1995; Chéron and Zins, 1997; Eggers and Eggers, 2011; Lebeau et al., 2012; Kabaday et al., 2013; Wu et al., 2014).

CA assumes that the utility of a product may be decomposed into criteria utilities, and that an aggregate utility function based on criteria utilities can be estimated (Louviere, 1988; Halme and Kallio, 2011). This method computes individual utilities of all vehicle criterion levels, called part-worth utilities, in order to obtain a rank ordering of the sums of each product set of utilities, allowing the comprehension of the behavioural process that leads to the choices of a population (Train, 2009; Kuhfeld, 2010).

Among the CA paradigms (rating, ranking and choice), Choice-Based Conjoint (CBC) was chosen for this study because its collection of data (consisting in simulated purchase decisions) is simpler and more realistic compared with product ratings (Jaeger et al., 2001; Borghi, 2009). CBC approximates the purchase process for products in a competitive market, where consumers have to screen a set of products and indicate which one they would buy (Orme, 2009).

Survey Analytics ${ }^{\circledR}$ software is used in this work to compute the utilities for each criterion level through the MNL model. This model is frequently used to analyse choice conjoint data at the aggregate level, and it is based on the Random Utility theory. For each consumer $n$ and for each alternative $i$, the random utility of the alternative $\left(U_{n i}\right)$ is a sum of known explanatory variables $\left(V_{n i}\right)$, named the systematic part of utility, plus a random part of utility unknown to the analyst $\left(\varepsilon_{n i}\right)$ (Ben-Akiva and Lerman, 1985):

$U_{n i}=V_{n i}+\varepsilon_{n i}$, for all $i \in C_{n}$

where, $C_{n}$ is the choice set that consumer $n$ faces; with $C_{n}=\{1, \ldots, \mathrm{J}\}$ (with $\mathrm{J}$ denoting the number of alternatives).

The MNL model is expressed by the following equation (Ben-Akiva and Lerman, 1985):

$P_{n}(i)=\frac{e^{V_{n i}}}{\sum_{j \in C_{n}} e^{V_{n j}}}$

where,

$P_{n}(i)=$ probability of consumer $n$ choosing alternative $i$

$V_{n i}=$ sum of part-worth utilities of alternative $i$ for consumer $n$

$V_{n j}=$ sum of part-worth utilities of alternative $j$ for consumer $n$ 
The choice probabilities for all alternatives add up to one, because consumers necessarily choose one of the available alternatives $(\mathrm{J})$

$\sum_{i=1}^{J} P_{n}(i)=1$

In CBC part-worth utilities are usually rescaled according to the zero-centered diffs method so that the sum within each criterion will be equal to zero (Lebeau et al., 2012).

\subsection{Study design}

The design of a consumer preferences study requires a definition of the alternatives and the criteria selected to compare the alternatives. In this study, the alternatives set comprised electric powertrains available in the Portuguese market and CV:

- BEV

- PHEV

- $\mathrm{HEV}$

- Gasoline

- Diesel

The brand and model of the vehicles were kept anonymous to avoid the influence of brand loyalty on preference judgements. With the exception of Glerum et al. (2012), who focused their analysis on a specific single brand of vehicles, all the previous studies chose to use unbranded vehicles in their analysis.

In order to distinguish between the vehicles some criteria had to be selected. The criteria selection was based on a pre-survey, designed to identify the most relevant criteria for consumers when buying a vehicle. In that preliminary survey each respondent (376 face-to-face interviews) freely named the criteria that were considered relevant for buying a car. The answers were analysed to obtain the frequency with which each criterion was mentioned (merging different designations for the same aspect). Among the most frequent criteria, (1) purchase price, (2) fuel consumption, (3) range and (4) $\mathrm{CO}_{2}$ emissions were selected because they provided a relevant differentiation between the powertrains of the vehicles set. Other frequently mentioned criteria, such as comfort or aesthetics, were not selected because they were not distinguishing characteristics of the powertrains. The selected criteria are among the most used in studies that assess consumer preferences for AFV (e.g. Bunch et al., 1993; Ewing and Sarigöllü, 2000; Potoglou and Kanaroglou, 2007; Lin and Greene, 2010; Hidrue et al., 2011; Qian and Soopramanien, 2011; Hackbarth and Madlener, 2013; Jensen et al., 2013). Besides these criteria, the survey included the possibility of having privileges for owners of BEV or PHEV, in order to verify the potential of these measures (existing in Portugal). The five criteria are described in Table III.

$<$ Table III $>$

\subsection{Survey description}

The preference elicitation survey comprised two main sections.

Section 1 - Stated preference questions

The first set of questions consisted of Stated Preference (SP) questions, namely CBC questions about combinations of different criteria levels defined beforehand. In order to capture non-linear utility functions within criteria, more than two levels were defined for each criterion (with the exception of the qualitative criterion privileges). In this study $\mathrm{CBC}$ consisted not only in asking respondents to choose the preferred alternative among a set of three, but also the least preferred one resulting in a ranking of the three vehicles in each choice set. This type of CBC questions is common in previous studies in the field (Dagsvik et al., 2002; Train, 2008; Dagsvik and Liu, 2009; Hensher and Greene, 2011; Hoen and Koetse, 2012). 
The CBC questions were obtained through an experimental design using the assigned levels for each criterion (see Table IV). As the combination of all criteria and levels would result in an overwhelming number of choice sets for each respondent to analyze $\left(4^{2} * 3^{2} * 2^{1}=288\right.$ profiles $)$ an efficient balanced overlap fractional factorial design was performed. This fractional factorial design that includes a small number of combinations of the criteria levels was performed using Survey Analytics ${ }^{\circledR}$ resulting in 20 choice sets to be evaluated. Then, four versions of the survey were used, each one consisting in five choice sets, with three alternatives each (see an example in figure 1). A version was randomly assigned to each respondent.

$<$ Table IV $>$

$<$ Figure 1 $>$

Section 2 - MCDA-based questions

In a second section of the survey respondents were presented with seven specific, but anonymous, vehicles with characteristics based on existing vehicles in the Portuguese market (Table V). Then, in a procedure based on the bisection method (for details see Belton and Stewart (2002)) respondents were asked to define a utility function for each criterion on a 0 to 10 scale. Performance levels corresponding to utility 0 and utility 10 were already defined and respondents were asked to define the performance levels only for the remaining scale values $(2.5,5$ and 7.5 utility). This allowed capturing nonlinearities in the utility functions. Then, respondents were also asked to directly define weights for each criterion, according to their preferences and the scales they had defined.

$<$ Table V $>$

In both sections, respondents were told to consider that all the vehicles were different versions of a model of the same brand, having the same design, comfort, warranty and safety. Besides these two sections respondents were also asked about their demographic characteristics, such as gender and age.

\subsection{Sampling and data collection}

A convenience sample was drawn according to two selection criteria: respondents must be older than 18 years old and should be potential vehicle buyers (respondents that intend or at least imagine themselves purchasing a vehicle in the near future).

Respondents were interviewed (face-to-face) between October and December 2012. Face-to-face interviews are more time consuming but they had several advantages compared with mail or online surveys by allowing interaction with the interviewer in real time and to ensure that respondents clearly understand the questions. For this reason, several recent studies chose to gather data about consumer preferences through personal interviews (Mills, 2008; Dagsvik and Liu, 2009; Zhang et al., 2011; Achtnicht et al., 2012), instead of the advanced online data collection software currently available.

The number of completed surveys was 252 but only 215 were considered as valid, after excluding surveys filled in incorrectly with inconsistent and/or missing data on relevant fields. Therefore, a total of 1075 CBC observations were collected.

Table VI presents the comparison of the respondents' characteristics of the sample and the characteristics of Portuguese consumers (INE, 2012). Females were underrepresented and consumers under 30 were strongly over represented. According to the reviewed studies in the section 2, AFV were more attractive to younger consumers (Ewing and Sarigöllü, 2000; Ziegler, 2012; Hackbarth and Madlener, 2013). The respondents in this study could therefore be more likely to choose AFV in a future purchase or to have a more favourable opinion regarding this type of vehicles. The misrepresentation of Portuguese population is a downside of selecting a convenience sample. However, as it can be seen in previous studies about consumer preferences, the absence of representativity is not a major concern if it allows gathering data 
from a group of consumers with more interesting characteristics for the study purposes (Beggs et al., 1981; Calfee, 1985; Potoglou and Kanaroglou, 2007; Caulfield et al., 2010; Zhang et al., 2011; Achtnicht et al., 2012).

$<$ Table VI $>$

\section{Results}

\subsection{Comparative analysis of CA and MCDA-based results}

\section{Part-worth function model}

As Halme and Kallio (2011) underlined, CA has been used in several disciplines because it enables the evaluation and analysis of utility functions. Figure 2 depicts the part-worth utilities of CA. This model derived from CA was able to reproduce correctly $73 \%$ of the choices made by the survey respondents. The main advantage of this approach is providing a ready interpretability of the plotted criteria part-worth functions, which allow observing the shapes of each preference function (Green and Srinivasan, 1978b).

MCDA-based data allowed having, for each respondent, utility functions for each criterion. These functions were defined directly by each respondent, whereas CA obtains these functions indirectly by means of parameter fitting (regression). In order to compare MCDA-based utility functions with the CA utility functions on an aggregate level, an average of each level (2.5, 5 and 7.5 in the $0-10$ scale) was made. The average MCDA-based utility functions are also plotted in figure 2, allowing the comparison of the utility functions.

It has been suggested that it is more likely to capture nonlinearities in the part-worth function for quantitative criteria when using CA than when using a data collection method that allows respondents to disaggregate preferences into components (such as MCDA-based questions in this study) (Sattler and Hensel-Borner, 2007). The results of this study corroborate this statement respecting to price and $\mathrm{CO}_{2}$ emissions, for which non-linearity obtained with CA contrasts with the (almost) linear utility function obtained through MCDAbased results. Range and fuel consumption on the other hand had similar results in their utility functions.

The analysis of the slope of the utility functions allows verifying how sensitive respondents are to changes in criteria levels: the highest the slope the highest the impact on the utility for the respondent. For example, in the fuel consumption criterion, the slope between $2 € / 100 \mathrm{~km}$ and $7 € / 100 \mathrm{~km}$ is steeper than the slope between $7 € / 100 \mathrm{~km}$ and $15 € / 100 \mathrm{~km}$, which means that respondents are most sensitive to an increment of fuel consumption from $2 € / 100 \mathrm{~km}$ to $4 € / 100 \mathrm{~km}$, for instance, than a similar increment from $12 € / 100 \mathrm{~km}$ to $14 € / 100 \mathrm{~km}$.

Comparing the two utility functions for each criterion, it can be seen that they are similar for all criteria except for $\mathrm{CO}_{2}$ emissions. The quasi-linear MCDA-based utility function differs from the non-linear CA utility function, in which the slope between $50 \mathrm{~g} / \mathrm{km}$ and $100 \mathrm{~g} / \mathrm{km}$ is much steeper than between $100 \mathrm{~g} / \mathrm{km}$ and $200 \mathrm{~g} / \mathrm{km}$, meaning that if the $\mathrm{CO}_{2}$ emissions increase within the $[50 \mathrm{~g} / \mathrm{km}, 100 \mathrm{~g} / \mathrm{km}$ ] interval this will have a significant impact on consumers utility, and therefore, on their vehicle purchase decisions.

As average values were used to plot MCDA-based utility functions the distribution of the criteria levels is presented in figure 3. This figure shows, for instance, that overall respondents have a high level of agreement about the price levels while the opposite is verified regarding the $\mathrm{CO}_{2}$ emissions levels (high dispersion of data).

$<$ Figure 2 $>$

$<$ Figure $3>$ 


\section{Ranking analysis}

Using CA and MCDA-based results, it is possible to obtain a ranking of the specific vehicles defined on Table V.

To obtain the CA ranking the overall utility of each vehicle was computed as follows (Malhotra, 2008):

$U(a)=\sum_{i=1}^{m} \sum_{j=1}^{k_{i}} \propto_{i j} x_{i j}$

Where,

$U(a)=$ overall utility of an alternative $a$

$\propto_{i j}=$ part-worth utility associated with the level $j\left(\mathrm{j}=1,2, \ldots k_{i}\right)$ of the criterion $i(\mathrm{i}=1,2, \ldots, m)$

$k_{i}=$ number of levels of criterion $i$

$m=$ number of criteria

$x_{i j}=\left\{\begin{array}{l}1 \text { if the level } j \text { of the criterion } i \text { is present in the alternative } a \\ 0, \text { otherwise }\end{array}\right.$

In MCDA, a global utility can be computed for each vehicle through the following equation (Keeney and Raiffa, 1993):

$U(a)=\sum_{i=1}^{m} w_{i} u_{i}(a)=w_{1} u_{1}(a)+w_{2} u_{2}(a)+\cdots+w_{m} u_{m}(a)$

Where

$u_{i}(a)=$ marginal utility of alternative $a$ in criterion $i$

$w_{i}=$ weight of criterion $i$ (i.e., weight of a marginal utility unit in criterion $i$ ).

The MCDA-based ranking, in an aggregate level, was computed through the formula above using the levels average already computed and also the criteria weights average of all respondents. The distribution of the weights is presented in figure 4. It should be noted that these weights reflect scale trade-offs that depend on the range of values considered, rather than the intuitive notion of criteria importance.

Figure 5 presents the plot of the global rankings that represent the average preferences of all respondents. The rankings were plotted in order to enable verifying the magnitude of the utility differences between ranking positions. Through the analysis of the rankings some comments can be made. First, BEV1 and BEV2 are among the bottom three in both rankings. This can be due to a large resistance of respondents to BEV that can be explained by their non-competitive characteristics regarding mainly to the limited range, higher price, or possibly other factors not considered in this study such as batteries lifetime, long charging times, etc. Second, the positions of BEV1 and BEV2 in both rankings suggest that privileges were more important in the MCDA-based ranking. Third, there are HEV and PHEV powertrains in the top three positions (in both rankings), which means that the characteristics of these vehicles potentially suit consumer preferences and thus are the most promising AFV in the short term, while uncertainties and psychological resistance with regards to BEV are still significant. Fourth, Gasoline is the least preferred vehicle. Gasoline vehicles used to be dominant in Portugal, but the share of Gasoline vehicles has been decreasing steadily and now they represent less than $30 \%$ of new vehicle sales (vs. around $70 \%$ diesel) (ACAP, 2013). The unfavourable position of the Gasoline vehicle can represent an opportunity to try to capture those consumers to the AFV market. 
$<$ Figure 4>

$<$ Figure 5 $>$

\section{Relevance of criteria}

The relevance of each criterion for CA, using the scaled part-worth utilities, was assessed through the computation of the relative importance of each criterion in consumer purchases, $w_{i}$, in which the part-worth range of each criterion is normalized so that the $m$ criteria importance adds up to unity (Malhotra, 2008):

$w_{i}=\frac{I_{i}}{\sum_{j=1}^{m} I_{j}}$

where $I_{i}$ denotes the difference between the highest and lowest part-worth utility of criterion $i$ :

$I_{i}=\left\{\max _{j}\left(\propto_{i j}\right)-\min _{j}\left(\propto_{i j}\right)\right\}$, for each criterion $i$

Equation (5) yields:

$\sum_{i=1}^{m} w_{i}=1$

According to CA, for the range of criteria levels considered in this study, fuel consumption was the most relevant criterion, followed by price, range, $\mathrm{CO}_{2}$ emissions and privileges (figure 6). These results mean that fuel consumption was the most influential criterion, as previously concluded in other studies (Hidrue et al., 2011; Graham-Rowe et al., 2012), by contributing in 33\% to the decision-making process regarding the vehicle purchase choice while price contributes with $24 \%$ and the existence of privileges does not have much influence on the purchase decision.

The criteria importance considering the MCDA-based results was obtained through the computation of the weights average across all respondents. The weights of price and fuel consumption are the ones with highest value, and the difference between them is not statistically significant (using a paired t-test the hypothesis that they are equal was not rejected for a level of significance equal to 0.01 once a p-value equal to 0.016 was obtained). Together, price and fuel consumption contribute with more than $50 \%$ to the overall utility of a vehicle.

$<$ Figure $6>$

\subsection{Sensitivity analysis of $C A$ results}

This section exemplifies the potential use of the results obtained in this study, considering the CA results (a similar analysis can be performed with the MCDA-based results). This section reports on two sensitivity analyses concerning the criteria that, according to this study, mostly influenced vehicle purchase decisions (price and fuel consumption), in order to verify which could be the impact of changing these criteria values on the vehicles ranking. The first analysis consisted in the reduction of the purchase price of BEV. As depicted on Table VII, BEV price has to decrease $5000 €$ from its current price for this vehicle to be the respondents first choice. This suggests that a purchase subsidy, with the current BEV price, could be more influent on consumer purchase decision than it was in the past.

The second analysis concerns an increase in the fuel prices (Gasoline and Diesel), maintaining the price of electricity unchanged (Table VIII). Some observations can be done respecting to this fuel price increment: a) the vehicles ranking does not change until the increment of fuel price reaches $70 \%(2,633 €$ and $2,292 €$ per 
liter of Gasoline and Diesel respectively); b) even with significant higher fuel costs (up to 90\%) Diesel vehicles maintain the first position in the ranking, which shows that their other criteria values compensate this cost increment; c) for a BEV to reach the first position of the ranking the fuel price has to double, which points out that although the low cost of energy is one of the main advantages of BEV, this characteristic is significant for vehicle purchase decisions only in a scenario where the Gasoline and Diesel prices are considered unbearable for consumers.

$<$ Table VII $>$

$<$ Table VIII $>$

\section{Conclusions}

This study aimed to provide insight on consumer preferences for EV and it extends previous research in a number of ways:

- It centered the analysis on consumer preferences in Portugal; to the authors' best knowledge this is the first study focused on the analysis of consumer preferences in the Portuguese market;

- It included in the analysis a larger vehicle set (the most realistic for the Portuguese market);

- It provided a new comparative analysis of consumer preferences data; and

- It presented high-resolution part-worth models.

The computation of the relative importance of each criterion allowed verifying that monetary criteria are those influencing vehicle purchase decisions the most according to both survey approaches. The importance of price confirmed its major role in the adoption process and the acceptability of new vehicle technologies (Choy and Prizzia, 2010; Eggers and Eggers, 2011). The significant influence of fuel consumption can be linked to the progressive increase of fuel prices in the recent years, which motivates consumers' concern and, consequently, could contribute to its higher relevance on future purchase decisions. However, the sensitivity analysis suggests that the fuel price must increase at least $70 \%$ to influence consumer preferences for EV, which means that the low fuel cost for EV does not yet compensate their limitations. This result suggests that any policy involving extra taxes for fuels that aim promoting AFV circulation will not be effective in a short-term. In terms of price, on the other hand, a decrease of 3,000€ for BEV would place these vehicles in a more favourable position and a decrease of $5000 €$ would make them the first choice of the average respondent. It should be noted that a decrease of $5000 €$ would make the BEV cost approximately the same as the Diesel vehicle, given the current cost of a BEV $(30,000 €)$. This contrasts with the situation in the past when the BEV cost $35,000 €$ and the $5000 €$ subsidy was insufficient to attract many buyers.

The plot of CBC part-worth utilities showed a surprising impact on respondents' utility when changing the $\mathrm{CO}_{2}$ emissions from $50 \mathrm{~g} / \mathrm{km}$ to $100 \mathrm{~g} / \mathrm{km}$. The fact that the sample over represents females and younger consumers that, according to previous studies, had been considered more environmental conscious (Achtnicht et al., 2012; Hackbarth and Madlener, 2013), is a possible explanation for this high sensitivity to a small increase of $\mathrm{CO}_{2}$ emissions. Marketing campaigns, that emphasize the major benefits of $\mathrm{EV}$ regarding their overall reduced environmental impacts, directed for this more sensitive market segment could be a strategy to encourage an increment of EV circulation.

Privileges, at the current market conditions, were not a relevant factor to raise the acceptance of EV among respondents, which corroborates the findings of previous studies on consumer preferences about AFV in Canada (Ewing and Sarigöllü, 2000; Potoglou and Kanaroglou, 2007) and USA (Gallagher and Muehlegger, 2007). However, it should be noted that MCDA-based results revealed a higher importance of privileges on consumer decisions when compared with $\mathrm{CBC}$ results. These results underline that providing these benefits for EVs owners is not a priority policy as long as other technical barriers that are responsible for consumers' concerns are not improved. Nevertheless, it is interesting to note that EV advantages were valued by respondents.

This study confirms that consumers still have concerns in the adoption of EV. This could be explained by limitations that consumers feel these vehicles have and by the higher price, compared to $\mathrm{CV}$. The favourable 
position of PHEV in the rankings makes the promotion of this type of vehicle an interesting path to exploit as potential intermediates to the diffusion of EV, as Keith (2012) had concluded about HEV regarding the USA market. On the other hand, the consistent bad results of Gasoline vehicles, and knowing that in 2013 there were more than 2 million Gasoline vehicles (approximately half of the light-duty passenger vehicle fleet) in circulation in Portugal (INE, 2014), means that there is a large market potential for electric powertrains in Portugal that should try to capture the preference of the current owners of Gasoline vehicles. A policy that could push the market into trading in Gasoline vehicles for electric powertrains could be providing an extra incentive for car scrappage schemes for older (mostly Gasoline) vehicles. The success of these strategies would allow mitigating the overall environmental impact of the transports sector by increasing the circulation of more environmental friendly vehicles.

Future research is yet needed to address limitations of this study. First, the sample is not a perfect representation of the Portuguese population, despite its relatively large size. Therefore, the conclusions of this study are valid first and foremost (but not only) for the sample of this study. Second, it would be interesting to compute individual part-worth utilities in the future in order to allow an analysis of clusters of consumer preferences, considering their demographic characteristics and driving habits.

\section{References}

Achtnicht, M., Bühler, G., Hermeling, C. (2012)., "The impact of fuel availability on demand for alternativefuel vehicles", Transportation Research Part D: Transport and Environment, Vol. 17 No. 3, pp. 262269.

Ahn, J., Jeong, G., Kim, Y. (2008), "A forecast of household ownership and use of alternative fuel vehicles: A multiple discrete-continuous choice approach", Energy Economics, Vol. 30 No. 5, pp. 2091-2104.

Beggs, S., Cardell, S. (1980), "Choice of smallest car by multi-vehicle households and the demand for electric vehicles", Transportation Research Part A, Vol. 14 No. 5, pp. 398-404.

Beggs, S., Cardell, S., Hausman, J. (1981), "Assessing the potential demand for electric cars", Journal of Econometrics, Vol. 16 No.1, pp. 1-19.

Belton, V., Stewart, T. (2002), Multiple Criteria Decision Analysis: An Integrated Approach, Kluwer, Boston.

Ben-Akiva, M., Lerman, S. (1985), Discrete choice analysis: theory and application to travel demand. MIT Press, Cambridge, US.

Borghi, C. (2009), Discrete choice models for marketing: new methodologies for optional features and bundles, Master thesis University Leiden, Mathematic Institute.

Brownstone, D., Bunch, D.S., Train, K. (2000), "Joint mixed logit models of stated and revealed preferences for alternative-fuel vehicles", Transportation Research Part B: methodological, Vol. 34 No. 5, pp. 315338.

Bunch, D.S., Golob, T.F., Occhiuzzo, G.P. (1993), "Demand for clean-fuel vehicles in California: a discretechoice stated preference pilot project", Transportation Research Part A, Vol. 27 No.3, pp. 237-253.

Calfee, J. (1985), "Estimating the demand for electric automobiles using fully disaggregated probabilistic choice analysis", Transportation Research Part B, Vol. 19 No. 4, pp. 287-301. 
Caulfield, B., Farrell, S., McMahon, B. (2010), "Examining individuals preferences for hybrid electric and alternatively fuelled vehicles", Transport Policy, Vol. 17 No. 6, pp. 381-387.

Choy, D., Prizzia, R. (2010), "Consumer behaviour and environmental quality in Hawaii", Management of Environmental Quality: An International Journal, Vol. 21 No.3, pp. 290-298.

Chéron, E., Zins, M. (1997), "Electric Vehicle Purchasing Intentions: The Concern over Battery charge duration", Transportation Research Part A: Policy and Practice, Vol. 31 No. 3, pp. 235-243.

Dagsvik, J.K., Wennemo, T., Wetterwald, D.G., Aaberge, R. (2002), "Potential demand for alternative fuel vehicles", Transportation Research Part B: Methodological, Vol. 36 No. 4, pp. 361-384.

Dagsvik, J.K., Liu, G. (2009), "A Framework for Analyzing Rank Ordered Data with Application to Automobile Demand", Transportation Research Part A: Policy and Practice, Vol. 43 No. 1, pp. 1-12.

EUROSTAT (2011), Energy, transport and environment indicators 2011, European Comission.

Eggers, F., Eggers, F. (2011), "Where have all the flowers gone Forecasting green trends in the automobile industry with a choice-based conjoint adoption model", Technological Forecasting \& Social Change, Vol. 78 No. 1, pp. 51-62.

Ewing, G., Sarigöllü, E. (1998), "Car fuel-type choice under travel demand management and economic incentives", Transportation Research Part D: Transport and Environment, Vol. 3 No. 6, pp. 429-444.

Ewing, G., Sarigöllü, E. (2000), "Assessing Consumer Preferences for Clean-Fuel Vehicles: A Discrete Choice Experiment", Journal of Public Policy \& Marketing, Vol. 19 No. 1, pp. 106-118.

Gallagher, K., Muehlegger, E. (2007), "Giving Green to get Green? The Effect of Incentives and Ideology on Hybrid Vehicle Adoption", Journal of Environmental Economics and Management, Vol 61 No.1, pp.115.

Garling, A., Thogersen, J. (2001) "Marketing of electric vehicles". Business Strategy and the Environment Vol. 10 No. 1, pp. 53-65.

Glerum, A., Thémans, M., Bierlaire, M. (2011), "Modeling demand for electric vehicles: the effect of car users' attitudes and perceptions", paper presented at the Second International Choice Modeling Conference, 4-6 July, Leeds, UK.

Glerum, A., Stankovikj, L., Thémans, M., Bierlaire, M. (2013), "Forecasting the demand for electric vehicles: accounting for attitudes and perceptions", Transportation Science, Vol. 48 No. 4, pp. 483-499.

Golob, T., Kitamura, R., Bradley, M., Bunch, D. (1993), "Predicting the market penetration of electric and clean-fuel vehicles", Science of the total environment, Vol. 134 No. 1, pp. 371-381.

Graham-Rowe, E., Gardner, B., Abraham, C., Skippon, S., Dittmar, H., Hutchins, R., Stannard, J. (2012), "Mainstream consumers driving plug-in battery-electric and plug-in hybrid electric cars: A qualitative analysis of responses and evaluations", Transportation Research Part A: Policy and Practice, Vol. 46 No. 1, pp. 140-153.

Green, P., Srinivasan, V. (1978a), "Evolution of the household vehicle fleet: Anticipating fleet composition, PHEV adoption and GHG emissions in Austin, Texas", Journal of consumer research, Vol. 45 No. 8, pp. 103-123. 
Green, P., Srinivasan, V. (1978b), "Conjoint analysis in consumer research: issues and outlook", Journal of consumer research, Vol. 5 No. 2, pp. 103-123.

Green, P.E., Krieger, A.M., Wind, Y. (2001), "Thirty Years of Conjoint Analysis: Reflections and Prospects", Interfaces, Vol. 31 No. 3, pp. 56-73.

Hackbarth, A., Madlener, R. (2013), "Consumer preferences for alternative fuel vehicles: A discrete choice analysis", Transportation Research Part D: Transport and Environment, Vol. 25, pp. 5-17.

Halme, M., Kallio, M. (2011), "Estimation methods for choice-based conjoint analysis of consumer preferences", European Journal of Operational Research, Vol. 214 No. 1, pp. 160-167.

Hensher, D.A., Greene, W.H. (2011), "Random Regret Minimization or Random Utility Maximization: An Exploratory Analysis in the Context of Automobile Fuel Choice", Journal of Advanced Transportation, Vol. 47 No. 7, pp. 667-678.

Hidrue, M.K., Parsons, G.R., Kempton, W., Gardner, M.P. (2011), "Willingness to pay for electric vehicles and their attributes", Resource and Energy Economics, Vol. 33 No. 3, pp. 686-705.

Hoen, A., Koetse, M. (2012), "A choice experiment on AFV Preferences of private car owners in the Netherlands", Working paper, Vol. 3 PBL .

INE (2012), "Censos 2011: Definitive results - Portugal". National Statistics Institute report.

INE (2013), "Statistics of Transports and Communications 2012", National Statistics Institute report, 2013 edition.

Jaeger, S.R., Hedderley, D., MacFie, H. (2001), "Methodological issues in conjoint analysis: a case study", European Journal of Marketing, Vol. 35 No. 11, pp. 1217-1237.

Jensen, A.F., Cherchi, E., Mabit, S.L. (2013), "On the stability of preferences and attitudes before and after experiencing an electric vehicle", Transportation Research Part D: Transport and Environment, Vol. 25, pp. 24-32.

Kabaday, E., Alan, A., Ozkan, B. (2013), "Effects of Product Properties on Consumer Preferences and Behaviours: A Study of the Automobile Market", International journal of management, Vol. 30 No. 2, pp. 349-361.

Kavalec, C. (1999), "Vehicle Choice in an Aging Population: Some Insights from a Stated Preference Survey for California", The energy journal, Vol. 20 No. 3, pp. 123-128.

Keeney, R., Raiffa, H. (1993), Decisions with Multiple Objectives: Preferences and Value Trade-Offs, Cambridge University Press, Cambridge.

Keith, D.R. (2012), Essays on the Dynamics of Alternative Fuel Vehicle Adoption: Insights from the Market for Hybrid-Electric Vehicles in the United States. Ph. D. Thesis - Massachusetts Institute of Technology Engineering Systems Division 2012., MIT.

Krems, P.J., Franke, T., Neumann, I., Cocron, P.( 2010), "Research methods to assess the acceptance of EVs - experiences from an EV user study", in Smart Systems Integration: 4th European Conference and Exhibition on Integration Issues of Miniaturized systems-MEMS, MOEMS, ICs and Electronic Components, 2010 Como, Italy, pp. 23-24. 
Kuhfeld, W.F. (2010), "Marketing Research Methods in SAS", Experimental Design, Choice, Conjoint and Graphical Techniques. SAS 9.2 Edition.

Kurani, K. (1994), "Demand for electric vehicles in hybrid households: an exploratory analysis", Transport Policy, Vol. 1 No.4, pp. 255-256.

Kurani, K., Sperling, D., Turrentine, T. (1996), "The Marketability of Electric Vehicles: Battery Performance and Consumer Demand for Driving Range", in Battery Conference on Applications and Advances, Eleventh Annual, IEEE, Long Beach, CA, pp. 153-158.

Kurani, K.S., Turrentine, T., Sperling, D. (1996), "Testing electric vehicle demand in hybrid households using a reflexive survey". Transportation Research Part D: Transport and Environment, Vol. 1 No. 2, pp. 131-150.

Lebeau, K., Mierlo, J.V., Lebeau, P., Mairesse, O., Macharis, C. (2012), "The market potential for plug-in hybrid and battery electric vehicles in Flanders: A choice-based conjoint analysis", Transportation Research Part D: Transport and Environment, Vol. 17 No. 8, pp. 592-597.

Lieven, T., Mühlmeier, S., Henkel, S., Waller, J.F. (2011), "Who will buy electric cars? An empirical study in Germany", Transportation Research Part D: Transport and Environment, Vol. 16 No. 3, pp. 236243.

Lin, Z., Greene, D. (2010), "Who Will More Likely Buy PHEV : A Detailed Market Segmentation Analysis", paper presented at The 25th World Battery, Hybrid and Fuel Cell Electric Vehicle Symposium \& Exhibition. 7-9 November, Shenzhen, China.

Louviere, J.J. (1988), "Conjoint analysis modelling of stated preferences: A review of theory, methods, recent developments and external validity", Journal of Transport Economics and Policy, Vol. 22 No. 1, pp. 93-119.

Malhotra, N. (2008), Marketing Research: An applied orientation, 5th edition. ed. Pearson Education, India.

Martins, A. (2011), "An assessment of recent trends on income taxation and environmental policy in Portugal", Management of Environmental Quality: An International Journal, Vol. 22 No. 4, pp. 418428.

Mills, M. (2008), "Environmentally - Active Consumers' Preference for Zero-Emission Vehicles : Public Sector and Marketing Implications", Journal of Nonprofit \& Public Sector Marketing, Vol. 19 No.1, pp. $1-13$.

Novemsky, N., Dhar, R., Schwarz, N., Simonson, I. (2007), "Preference Fluency in Choice", Journal of Marketing Research, Vol. 44 No. 3, pp. 347-356.

Orme, B.K. (2009), "Which conjoint method should I use?", Research paper series, Sawtooth Software.

Potoglou, D., Kanaroglou, P.S. (2007), "Household demand and willingness to pay for clean vehicles", Transportation Research Part D: Transport and Environment, Vol. 12 No. 4, pp. 264-274.

Qian, L., Soopramanien, D. (2011), "Heterogeneous consumer preferences for alternative fuel cars in China", Transportation Research Part D: Transport and Environment, Vol. 16 No. 8, pp. 607-613. 
Sattler, H., Hensel-Borner, S. (2007), "A comparison of conjoint measurement with self-explicated approaches", in: Gustaffson, A., Herrmann, A., Huber, F. (Eds.), Conjoint Measurement: Methods and Application. Springer-Verlag, Berlin, Germany, pp. 67-76.

Segal, R. (1995), "Forecasting the Market for Electric Vehicles in California Using Conjoint Analysis", The Energy Journal, Vol. 16 No. 3, pp. 89-111.

Steiner, M., Helm, R., Szelig, A. (2011), "Preference Measurement and Unacceptable Attribute Levels", Working Paper, University of Regensburg, Regensburg

Thesen, G., Langhelle, O. (2008), "Awareness, acceptability and attitudes towards hydrogen vehicles and filling stations: A Greater Stavanger case study and comparisons with London", International Journal of Hydrogen Energy, Vol. 33 No. 21, pp. 5859-5867.

Tompkins, M., Bunch, D. (1998), "Determinants of alternative fuel vehicle choice in the continental United States", Transportation Research Record: Journal of the Transportation Research Board, Vol. 1641 No.1, pp. 130-138.

Train, K. (2008), "EM Algorithms for nonparametric estimation of mixing distributions", Journal of Choice Modelling, Vol. 1 No. 1, pp. 40-69.

Train, K. (2009), Discrete Choice Methods with Simulation, Cambridge University Press, Cambridge.

Wu, W.Y., Liao, Y.K., Chatwuthikrai, A. (2014), "Applying conjoint analysis to evaluate consumer preferences toward subcompact cars", Expert Systems with Applications, Vol. 41 No. 6, pp. 2782-2792.

Zhang, Y., Yu, Y., Zou, B. (2011), "Analyzing public awareness and acceptance of alternative fuel vehicles in China: The case of EV", Energy Policy, Vol. 39 No. 11, pp. 7015-7024.

Ziegler, A. (2012), "Individual characteristics and stated preferences for alternative energy sources and propulsion technologies in vehicles: A discrete choice analysis for Germany", Transportation Research Part A: Policy and Practice, Vol. 46 No. 8, pp. 1372-1385. 
Table I: Consumer preferences studies for EV.

\begin{tabular}{|c|c|c|c|c|c|}
\hline Study & Country & Goal & Methodology & $\begin{array}{c}\text { Vehicles } \\
\text { compared }\end{array}$ & Type of Data \\
\hline $\begin{array}{l}\text { Beggs and } \\
\text { Cardell } \\
(1980)\end{array}$ & USA & $\begin{array}{l}\text { To obtain information useful } \\
\text { for projecting the demand for } \\
\text { EV }\end{array}$ & $\begin{array}{l}\text { Multinomial logit } \\
\text { model }\end{array}$ & N/A ${ }^{*}$ & $\begin{array}{c}\text { Wharton auto } \\
\text { characteristics } \\
\text { database and } \\
\text { Baltimore data set }\end{array}$ \\
\hline $\begin{array}{l}\text { Beggs et al. } \\
\qquad(1981)\end{array}$ & USA & $\begin{array}{l}\text { To assess the potential } \\
\text { demand for EV }\end{array}$ & $\begin{array}{l}\text { Ordered Logit } \\
\text { Model }\end{array}$ & $\begin{array}{l}\text { EV and CV } \\
\text { (gasoline) }\end{array}$ & $\begin{array}{c}\text { Stated } \\
\text { preferences }\end{array}$ \\
\hline Calfee (1985) & USA & $\begin{array}{l}\text { To estimate the potential } \\
\text { demand for EV and the } \\
\text { dispersion of preferences } \\
\text { across a subpopulation of the } \\
\text { public }\end{array}$ & $\begin{array}{l}\text { Multinomial logit } \\
\text { model }\end{array}$ & $\begin{array}{l}\text { EV and CV } \\
\text { (gasoline) }\end{array}$ & $\begin{array}{c}\text { Stated } \\
\text { preferences }\end{array}$ \\
\hline $\begin{array}{l}\text { Kurani } \\
(1994)\end{array}$ & USA & $\begin{array}{c}\text { To explore hypothetical } \\
\text { hybrid household vehicle use }\end{array}$ & $\begin{array}{l}\text { Standard statistical } \\
\text { techniques }\end{array}$ & $\mathrm{N} / \mathrm{A}^{*}$ & $\begin{array}{l}\text { Travel diaries } \\
\text { and Interactive } \\
\text { stated } \\
\text { preferences }\end{array}$ \\
\hline Segal (1995) & USA & To forecast EV purchases & $\mathrm{CA}$ & $\begin{array}{l}\text { EV and CV } \\
\text { (gasoline) }\end{array}$ & $\begin{array}{c}\text { Stated } \\
\text { preferences }\end{array}$ \\
\hline $\begin{array}{l}\text { Kurani et al. } \\
\text { (1996) }\end{array}$ & USA & $\begin{array}{l}\text { To examine household } \\
\text { consideration of EV within the } \\
\text { context of several processes }\end{array}$ & $\begin{array}{l}\text { Activity-based } \\
\text { approaches, gaming } \\
\text { simulations, } \\
\text { interactive stated } \\
\text { response methods } \\
\text { and reflexive design }\end{array}$ & $\begin{array}{l}\mathrm{EV}, \mathrm{HEV}, \mathrm{NGV} \\
\text { and CV } \\
\text { (gasoline) }\end{array}$ & $\begin{array}{c}\text { Interactive stated } \\
\text { preferences }\end{array}$ \\
\hline $\begin{array}{l}\text { Chéron and } \\
\text { Zins (1997) }\end{array}$ & Canada & $\begin{array}{c}\text { To determine which are the } \\
\text { most determinant factors } \\
\text { blocking the purchase of an } \\
\text { EV }\end{array}$ & $\begin{array}{l}\text { CA and Nominal } \\
\text { Group technique }\end{array}$ & $\mathrm{EV}$ & $\begin{array}{c}\text { Stated } \\
\text { preferences }\end{array}$ \\
\hline Mills (2008) & USA & $\begin{array}{c}\text { To identify factors that would } \\
\text { drive the preference-adoption } \\
\text { process of Zero emission } \\
\text { vehicles }\end{array}$ & $\begin{array}{l}\text { Discrete choice } \\
\text { experiment }\end{array}$ & $\mathrm{N} / \mathrm{A}^{*}$ & Focus groups \\
\hline $\begin{array}{l}\text { Krems et al. } \\
\qquad(2010)\end{array}$ & Germany & $\begin{array}{l}\text { To assess the challenges and } \\
\text { potentials of EV for everyday } \\
\text { mobility }\end{array}$ & $\mathrm{CA}$ & EV & $\begin{array}{c}\text { Stated } \\
\text { preferences }\end{array}$ \\
\hline $\begin{array}{l}\text { Hidrue et al. } \\
\qquad(2011)\end{array}$ & USA & $\begin{array}{l}\text { To analyse to which extent } \\
\text { experience affects individual } \\
\text { preferences and the impact of } \\
\text { attitudes on the choice } \\
\text { between EV and CV }\end{array}$ & $\begin{array}{l}\text { Multinomial logit } \\
\text { model }\end{array}$ & $\begin{array}{l}\text { EV and CV } \\
\text { (gasoline) }\end{array}$ & $\begin{array}{c}\text { Stated } \\
\text { preferences }\end{array}$ \\
\hline
\end{tabular}




\begin{tabular}{|c|c|c|c|c|c|}
\hline Study & Country & Goal & Methodology & $\begin{array}{c}\text { Vehicles } \\
\text { compared }\end{array}$ & Type of Data \\
\hline $\begin{array}{l}\text { Lieven et al. } \\
\qquad(2011)\end{array}$ & Germany & $\begin{array}{l}\text { To forecast the market } \\
\text { potential of electric vehicles }\end{array}$ & $\begin{array}{l}\text { Correspondence } \\
\text { analysis }\end{array}$ & $\begin{array}{l}\text { EV and CV } \\
\text { (gasoline) }\end{array}$ & $\begin{array}{c}\text { Stated } \\
\text { preferences }\end{array}$ \\
\hline $\begin{array}{l}\text { Zhang et al. } \\
\qquad(2011)\end{array}$ & China & $\begin{array}{l}\text { To identify the factors that } \\
\text { impact consumers' preference } \\
\text { for AFV }\end{array}$ & $\begin{array}{l}\text { Binary logistic } \\
\text { regression models }\end{array}$ & EV & $\begin{array}{c}\text { Stated } \\
\text { preferences }\end{array}$ \\
\hline $\begin{array}{l}\text { Eggers and } \\
\text { Eggers } \\
(2011)\end{array}$ & Germany & $\begin{array}{l}\text { To apply choice-based } \\
\text { conjoint to analyse the future } \\
\text { acceptance of AFV }\end{array}$ & $\mathrm{CA}$ & $\begin{array}{l}\text { EV, Range- } \\
\text { extend electric, } \\
\text { HEV and CV } \\
\text { (gasoline) }\end{array}$ & $\begin{array}{c}\text { Stated } \\
\text { preferences }\end{array}$ \\
\hline $\begin{array}{l}\text { Glerum et al. } \\
\qquad(2011)\end{array}$ & Switzerland & $\begin{array}{l}\text { To address several issues } \\
\text { related to the evaluation of the } \\
\text { demand for EV, i.e. related to } \\
\text { the survey design, demand } \\
\text { models and forecasting }\end{array}$ & Logit model & $\begin{array}{l}\mathrm{EV} \text { and } \mathrm{CV} \\
\text { (gasoline and } \\
\text { diesel) }\end{array}$ & $\begin{array}{c}\text { Stated } \\
\text { preferences }\end{array}$ \\
\hline $\begin{array}{l}\text { Lebeau et al. } \\
\qquad(2012)\end{array}$ & Belgium & $\begin{array}{l}\text { To examine the market } \\
\text { potential in Flandres } \\
\text { (Belgium) of PHEV and EV }\end{array}$ & $\mathrm{CA}$ & $\begin{array}{l}\text { EV, PHEV and } \\
\text { CV (gasoline and } \\
\text { diesel) }\end{array}$ & $\begin{array}{c}\text { Stated } \\
\text { preferences }\end{array}$ \\
\hline $\begin{array}{l}\text { Ziegler } \\
(2012)\end{array}$ & Germany & $\begin{array}{c}\text { To examine the preferences } \\
\text { for alternative energy sources } \\
\text { or propulsion technologies in } \\
\text { vehicles and particularly for } \\
\text { EV }\end{array}$ & $\begin{array}{l}\text { Multinomial Probit } \\
\text { models }\end{array}$ & $\begin{array}{l}\text { EV, HEV, CNG, } \\
\text { Fuel cell vehicles } \\
\text { and CV (diesel } \\
\text { and gasoline) }\end{array}$ & $\begin{array}{c}\text { Stated } \\
\text { preferences }\end{array}$ \\
\hline $\begin{array}{l}\text { Glerum et al. } \\
\text { (2013) }\end{array}$ & Switzerland & $\begin{array}{l}\text { To present an integrated } \\
\text { methodology to forecast the } \\
\text { demand for EV, from data } \\
\text { collection to prediction }\end{array}$ & $\begin{array}{l}\text { Hybrid choice } \\
\text { models }\end{array}$ & $\begin{array}{l}\mathrm{EV} \text { and } \mathrm{CV} \\
\text { (gasoline and } \\
\text { diesel) }\end{array}$ & $\begin{array}{c}\text { Stated } \\
\text { preferences }\end{array}$ \\
\hline $\begin{array}{l}\text { Jensen et al. } \\
\qquad(2013)\end{array}$ & Denmark & $\begin{array}{l}\text { To analyse to which extent } \\
\text { experience affects individual } \\
\text { preferences and the impact of } \\
\text { attitudes on the choice } \\
\text { between EV and CV }\end{array}$ & Mixed logit model & $\begin{array}{l}\mathrm{EV} \text { and } \mathrm{CV} \\
\text { (gasoline and } \\
\text { diesel) }\end{array}$ & Stated preferences \\
\hline
\end{tabular}


Table II: Consumer preference studies for AFV that used CA.

\begin{tabular}{|c|c|c|c|}
\hline Study & Focus & Method & Part-worth utilities analysis incorporated in the study \\
\hline Segal (1995) & EV & Conjoint analysis & - Computation of the relative importance of each criterion \\
\hline $\begin{array}{l}\text { Chéron and Zins } \\
\text { (1997) }\end{array}$ & $\mathrm{EV}$ & Conjoint analysis & $\begin{array}{l}\text { - Computation of the relative importance of each criterion } \\
\text { - Comparison of the relative importance of criteria with values } \\
\text { directly allocated to each criterion (sum equal to } 100 \% \text { ) }\end{array}$ \\
\hline $\begin{array}{l}\text { Ewing and } \\
\text { Sarigöllü (2000) }\end{array}$ & AFV & Discrete choice experiment & - Analysis of the part-worth graphs \\
\hline $\begin{array}{l}\text { Eggers and } \\
\text { Eggers }(2011)\end{array}$ & $\mathrm{EV}$ & $\begin{array}{l}\text { Choice-based conjoint } \\
\text { analysis }\end{array}$ & $\begin{array}{l}\text { - Preference distribution of the part-worth utility of each level of } \\
\text { criterion } \\
\text { - Sensitivity analysis of criteria values (effect on market shares) }\end{array}$ \\
\hline $\begin{array}{l}\text { Lebeau et al. } \\
(2012)\end{array}$ & $\begin{array}{l}\text { EV and } \\
\text { PHEV }\end{array}$ & $\begin{array}{l}\text { Choice-based conjoint } \\
\text { analysis }\end{array}$ & $\begin{array}{l}\text { - Scenario analysis (effect on market shares) } \\
\text { - Sensitivity analysis of criteria values (effect on market shares) }\end{array}$ \\
\hline $\begin{array}{l}\text { Kabaday et al. } \\
\text { (2013) }\end{array}$ & $\mathrm{CV}$ & Conjoint analysis & $\begin{array}{l}\text { - Computation of the relative importance of each criterion } \\
\text { - Crossing importance with demographics }\end{array}$ \\
\hline Wu et al. (2014) & $\mathrm{CV}$ & Conjoint analysis & $\begin{array}{l}\text { - Plot of part-worth utilities for each criterion } \\
\text { - Computation of the relative importance of each criterion }\end{array}$ \\
\hline
\end{tabular}

Table III: Description of criteria.

\begin{tabular}{|c|c|c|}
\hline Criteria & Description & Units \\
\hline Price & Cost to acquire a vehicle & $€$ \\
\hline Range & $\begin{array}{l}\text { Distance that can be driven without fuelling/charging the } \\
\text { vehicle }\end{array}$ & $\mathrm{km}$ \\
\hline Fuel consumption & Cost to drive $100 \mathrm{~km}$ & $€ / 100 \mathrm{~km}$ \\
\hline $\mathrm{CO}_{2}$ emissions & $\begin{array}{l}\text { Quantity of } \mathrm{CO}_{2} \text { emissions released to the environment } \\
\text { during the usage phase of the vehicle (including electricity } \\
\text { generation in the case of PHEV and EV) }\end{array}$ & $\mathrm{g} / \mathrm{km}$ \\
\hline Privileges & $\begin{array}{l}\text { Existence of privileges to the vehicle owners, namely the } \\
\text { possibility of parking in reserved parking spots; access to } \\
\text { historic city centres (usually prohibited) and circulation in } \\
\text { high priority lanes in cities (Yes/No) }\end{array}$ & $\mathrm{N} / \mathrm{A}^{*}$ \\
\hline
\end{tabular}


Table IV: Criteria levels for experimental design.

\begin{tabular}{ll}
\hline Criteria & Levels \\
\hline Price & $21,000 € / 26,000 € / 30,000 € / 34,000 €$ \\
Range & $200 \mathrm{~km} / 500 \mathrm{~km} / 800 \mathrm{~km} / 1300 \mathrm{~km}$ \\
Fuel consumption (per 100 km) & $2 € / 7 € / 15 €$ \\
CO2 emissions (per km) & $50 \mathrm{~g} / 100 \mathrm{~g} / 200 \mathrm{~g}$ \\
Privileges & Yes / No \\
\hline
\end{tabular}

Table V: Characteristics of the set of vehicles analysed in this study.

\begin{tabular}{cccccc}
\hline & $\begin{array}{c}\text { Price } \\
(€)\end{array}$ & $\begin{array}{c}\text { Range } \\
(\mathrm{k})\end{array}$ & $\begin{array}{c}\text { Fuel consumption } \\
(€ / 100 \mathrm{~km})\end{array}$ & $\begin{array}{c}\mathrm{CO}_{2} \text { emissions } \\
(\mathrm{g} / \mathrm{km})\end{array}$ & Privileges \\
\hline BEV1 $^{\text {a) }}$ & 30000 & 175 & 2.4 & 50 & Yes \\
BEV2 $^{\text {a) }}$ & 29000 & 175 & 2.4 & 50 & No \\
HEV & 25500 & $2+1200^{\mathrm{b})}$ & $6.5^{\mathrm{c})}$ & 110 & No \\
Gasoline $^{\text {biesel }}$ & 25700 & 833 & $11.1^{\mathrm{c})}$ & 170 & No \\
PHEV1 $^{\text {a) }}$ & 24900 & 1300 & $6.3^{\mathrm{d})}$ & 130 & No \\
PHEV2 $^{\text {a) }}$ & 28500 & $20+1180^{\mathrm{b})}$ & $4.7^{\mathrm{c})}$ & 100 & Yes \\
\hline
\end{tabular}

a) The only difference between BEV1 and BEV2, and between PHEV1 and PHEV2 is the existence of privileges

b) Range of the electric engine + range of the internal combustion engine

c) Considering Gasoline price $=1,549 € / \mathrm{L}$

d) Considering Diesel price $=1,348 € / \mathrm{L}$

Table VI: Demographics of consumers.

\begin{tabular}{lcc}
\hline & \multicolumn{2}{c}{ Percent (\%) } \\
\hline Variable & Sample & Portugal \\
$\begin{array}{l}\text { Gender } \\
\text { Female }\end{array}$ & 40 & 47 \\
Male & 60 & 53 \\
Age & & \\
$\quad<\mathbf{2 0}$ & 4 & 2 \\
{$[\mathbf{2 0 , 3 0}[$} & 54 & 12 \\
{$[\mathbf{3 0 , 4 0}[$} & 8 & 15 \\
{$[\mathbf{4 0 , 5 0}[$} & 10 & 15 \\
{$[\mathbf{5 0 , 6 0}[$} & 20 & 13 \\
$>=\mathbf{6 0}$ & 4.3 & 16 \\
\hline
\end{tabular}


Table VII: Sensitivity analysis: the effect of a purchase price reduction of BEV price on the ranking of the vehicles set.

\begin{tabular}{cccccccc}
\hline \multirow{2}{*}{ Ranking } & Base case & \multicolumn{7}{c}{ Purchase price reduction } \\
\cline { 2 - 7 } & scenario & $1000 €$ & $2000 €$ & $3000 €$ & $4000 €$ & $5000 €$ & $6000 €$ \\
\hline 1 & Diesel & Diesel & Diesel & Diesel & Diesel & BEV 1 & BEV 1 \\
2 & HEV & HEV & HEV & HEV & BEV 1 & Diesel & BEV 2 \\
3 & PHEV 1 & PHEV 1 & PHEV 1 & BEV 2 & BEV 2 & BEV 2 & Diesel \\
4 & PHEV 2 & PHEV 2 & PHEV 2 & BEV 1 & HEV & HEV & HEV \\
5 & BEV 2 & BEV 2 & BEV 2 & PHEV 1 & PHEV 1 & PHEV 1 & PHEV 1 \\
6 & BEV 1 & BEV 1 & BEV 1 & PHEV 2 & PHEV 2 & PHEV 2 & PHEV 2 \\
7 & Gasoline & Gasoline & Gasoline & Gasoline & Gasoline & Gasoline & Gasoline \\
\hline
\end{tabular}

Table VIII: Sensitivity analysis: the effect of fuel price increase on the ranking of the vehicles set.

\begin{tabular}{ccccccc}
\hline \multirow{2}{*}{ Ranking } & Base case & \multicolumn{5}{c}{ Fuel Price (Gasoline and Diesel) } \\
\cline { 3 - 6 } & scenario & $60 \%$ higher & $70 \%$ higher & $80 \%$ higher & $90 \%$ higher & $100 \%$ higher \\
\hline 1 & Diesel & Diesel & Diesel & Diesel & Diesel & BEV 2 \\
2 & HEV & HEV & HEV & BEV 2 & BEV 2 & Diesel \\
3 & PHEV 1 & PHEV 1 & PHEV 1 & BEV 1 & BEV 1 & BEV 1 \\
4 & PHEV 2 & PHEV 2 & BEV 2 & PHEV 1 & PHEV 1 & PHEV 1 \\
5 & BEV 2 & BEV 2 & PHEV 2 & HEV & HEV & PHEV 2 \\
6 & BEV 1 & BEV 1 & BEV 1 & PHEV 2 & PHEV 2 & HEV \\
7 & Gasoline & Gasoline & Gasoline & Gasoline & Gasoline & Gasoline \\
\hline
\end{tabular}


Figure 1. Example of a stated preference scenario.

\begin{tabular}{|c|c|c|c|c|c|c|}
\hline & Price & Range & Fuel consumption & $\mathrm{CO}_{2}$ Emissions & Privileges & Ranking \\
\hline Vehicle A & $34.000 €$ & $800 \mathrm{~km}$ & $2 € / 100 \mathrm{~km}$ & $50 \mathrm{~g} / \mathrm{km}$ & Yes & \\
\hline Vehicle B & $21.000 €$ & 800 km & $15 € / 100 \mathrm{~km}$ & $200 \mathrm{~g} / \mathrm{km}$ & No & \\
\hline \multirow[t]{2}{*}{ Vehicle C } & $26.000 €$ & $500 \mathrm{~km}$ & $2 € / 100 \mathrm{~km}$ & $50 \mathrm{~g} / \mathrm{km}$ & Yes & \\
\hline & Price & Range & Fuel consumption & $\mathrm{CO}_{2}$ Emissions & Privileges & Ranking \\
\hline Vehicle A & $21.000 €$ & $1300 \mathrm{~km}$ & $7 € / 100 \mathrm{~km}$ & $200 \mathrm{~g} / \mathrm{km}$ & No & \\
\hline Vehicle B & $34.000 €$ & $500 \mathrm{~km}$ & $7 € / 100 \mathrm{~km}$ & $50 \mathrm{~g} / \mathrm{km}$ & No & \\
\hline \multirow[t]{2}{*}{ Vehicle C } & $30.000 €$ & $800 \mathrm{~km}$ & $7 € / 100 \mathrm{~km}$ & $100 \mathrm{~g} / \mathrm{km}$ & No & \\
\hline & Price & Range & Fuel consumption & $\mathrm{CO}_{2}$ Emissions & Privileges & \multirow[t]{4}{*}{ Ranking } \\
\hline Vehicle A & $34.000 €$ & $800 \mathrm{~km}$ & $7 € / 100 \mathrm{~km}$ & $100 \mathrm{~g} / \mathrm{km}$ & Yes & \\
\hline Vehicle B & $30.000 €$ & 500 km & $2 € / 100 \mathrm{~km}$ & $100 \mathrm{~g} / \mathrm{km}$ & Yes & \\
\hline \multirow[t]{2}{*}{\begin{tabular}{|l|} 
Vehicle C \\
\end{tabular}} & $30.000 €$ & 1300 km & $2 € / 100 \mathrm{~km}$ & $50 \mathrm{~g} / \mathrm{km}$ & Yes & \\
\hline & Price & Range & Fuel consumption & $\mathrm{CO}_{2}$ Emissions & Privileges & \multirow[t]{4}{*}{ Ranking } \\
\hline Vehicle A & $21.000 €$ & $500 \mathrm{~km}$ & $2 € / 100 \mathrm{~km}$ & $100 \mathrm{~g} / \mathrm{km}$ & Yes & \\
\hline Vehicle B & $26.000 €$ & $500 \mathrm{~km}$ & $15 € / 100 \mathrm{~km}$ & $100 \mathrm{~g} / \mathrm{km}$ & No & \\
\hline \multirow[t]{2}{*}{ Vehicle C } & $30.000 €$ & $1300 \mathrm{~km}$ & $15 € / 100 \mathrm{~km}$ & $100 \mathrm{~g} / \mathrm{km}$ & No & \\
\hline & Price & Range & Fuel consumption & $\mathrm{CO}_{2}$ Emissions & Privileges & \multirow[t]{4}{*}{ Ranking } \\
\hline Vehicle A & $34.000 €$ & $500 \mathrm{~km}$ & $15 € / 100 \mathrm{~km}$ & $100 \mathrm{~g} / \mathrm{km}$ & No & \\
\hline \begin{tabular}{|l|} 
Vehicle B \\
\end{tabular} & $34.000 €$ & $200 \mathrm{~km}$ & $2 € / 100 \mathrm{~km}$ & $50 \mathrm{~g} / \mathrm{km}$ & No & \\
\hline Vehicle C & $26.000 €$ & $200 \mathrm{~km}$ & $7 € / 100 \mathrm{~km}$ & $200 \mathrm{~g} / \mathrm{km}$ & No & \\
\hline
\end{tabular}


Figure 2. Plot of part-worth utility functions.

Price

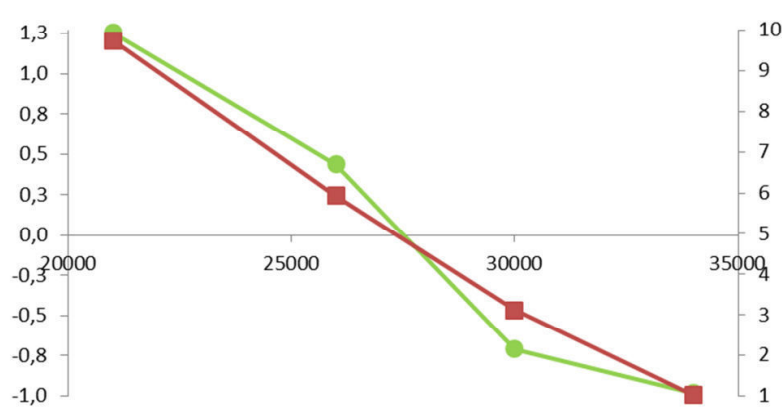

Fuel Consumption

\section{Range}



$\mathrm{CO}_{2}$ Emissions
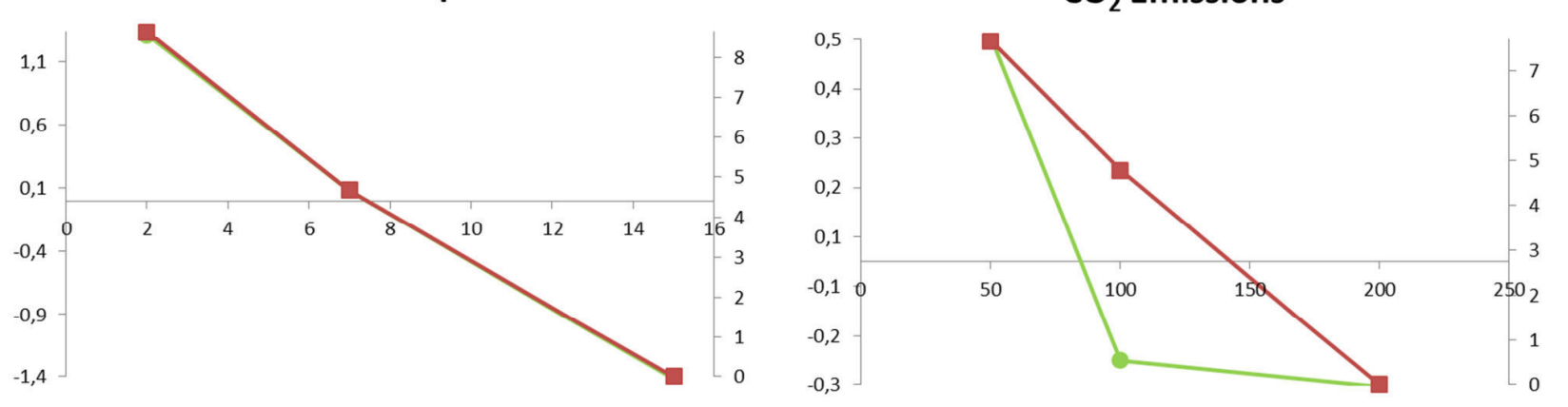

$\longrightarrow$ CA - MCDA-based 
Figure 3. Distribution of each criterion level (the dots represent the previously defined 0 and 10 levels for each criterion).

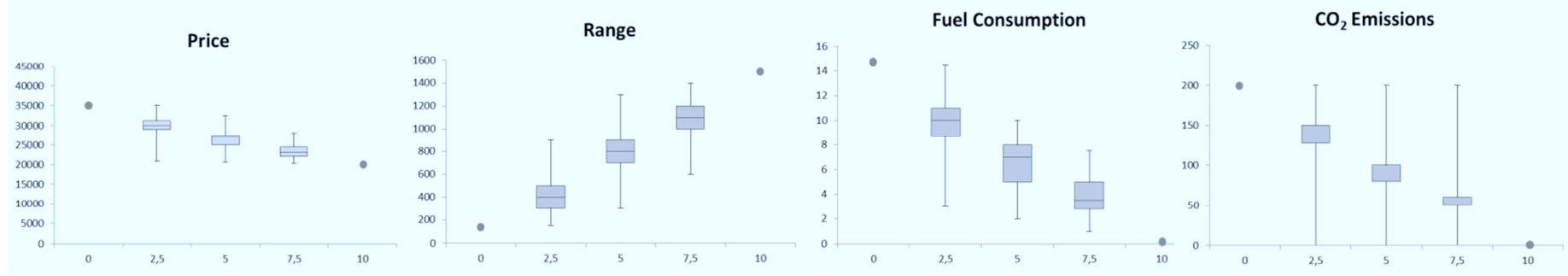

Figure 4. Distribution of the weights of MCDA-based results.

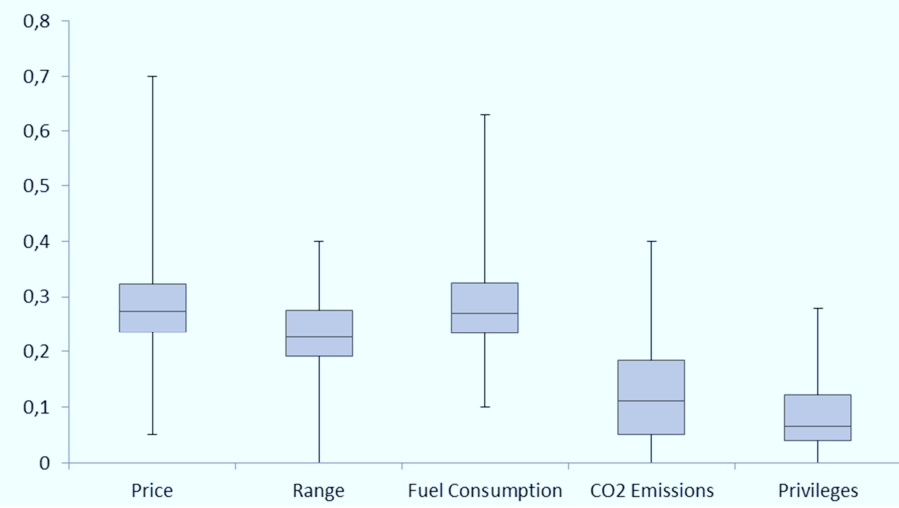

Figure 5. Plot of the CA and MCDA-based rankings.

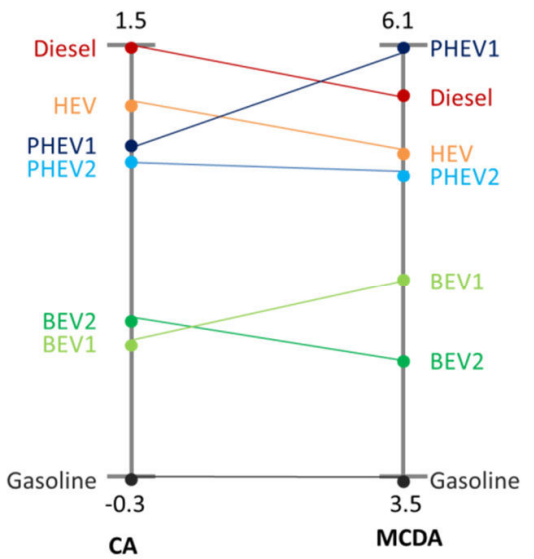


Figure 6. Relative importance of criteria.

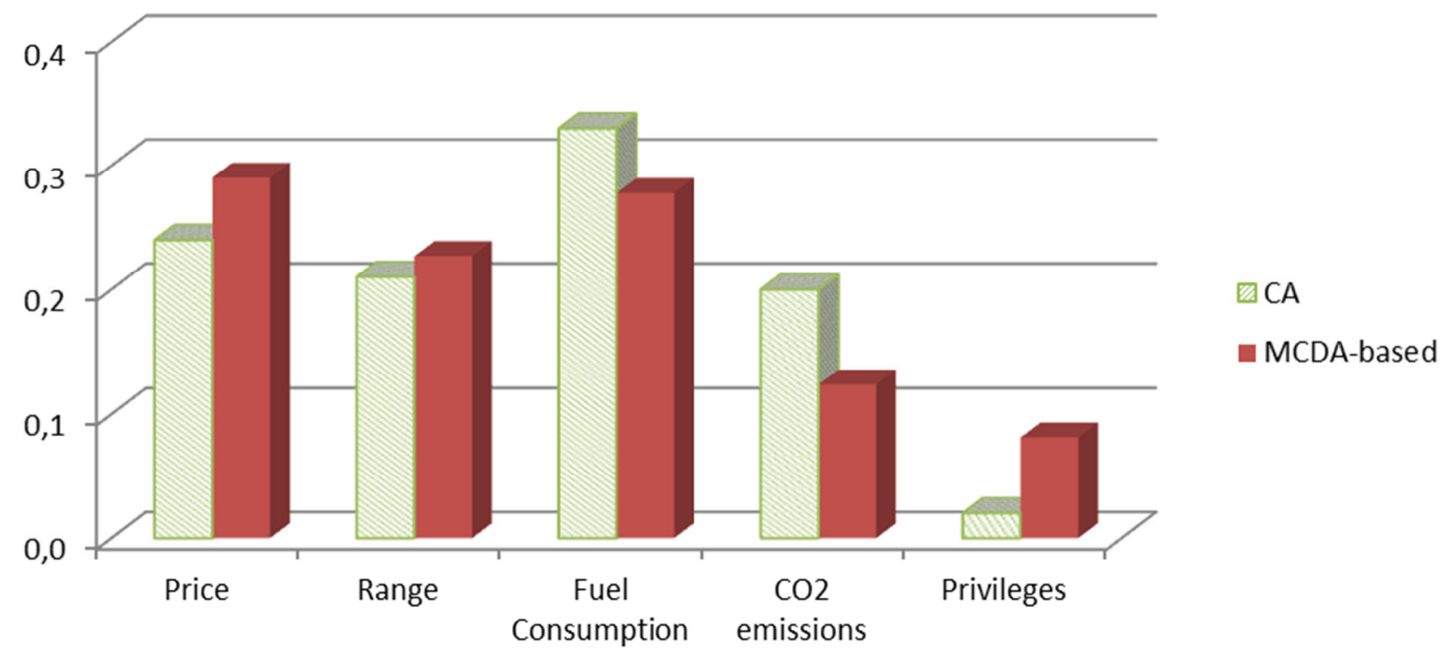

